are strongly modified when the nucleus in question is suffering a sufficiently rapid change in chemical environment (R. A. Ogg).

Conductimetric methods, using high-frequency oscillators, are useful for following ionizable systems in solution. At megacycle frequencies it is not necessary to have electrodes in contact with the solution and more rapid recording is possible (P. J. Elving). Changes in ion concentration during a fast reaction can be measured by using a rotating platinum-wire electrode in conjunction with an automatic recording polarograph (I. M. Kolthoff and W. L. Reynolds). One of the oldest electrochemical methods, which has seldom been applied, is "voltammetry at constant current' ( $P$. Delahay). It has certain advantages over polarography, but both methods are limited by the difficulties of theoretical analysis of reactions of higher order than the first.

The older methods of chemical kinetics, where the velocities of very fast reactions are inferred from a leisurely analysis of the final products, will continue to play an important part, especially as new tools, such as isotope-enriched molecules, become available (R. A. Ogg and W. T. Sutphen). With this wealth of experimental method the often-encountered statement that a reaction was 'too fast to follow' should disappear from the literature. The only danger appears to be the one mentioned by Prof. Melville in his introductory remarks, that one may become so impressed by the gadgetry that one loses sight of the purpose for which the gadget was designed. The final criterion by which any experimental technique must eventually be judged is the originality and reliability of the information which it provides.

George Porter

\section{MARINE BIOLOGY IN NATAL}

\section{BY ROBERT CLARKE}

National Institute of Oceanography, Wormley, Surrey

$\mathrm{L}_{\text {of }}$ IKE many other countries since the Second World War, South Africa now faces the problem Although she a rapidly increasing population. menaced by a widespread soil erosion, and it is natural that South Africa should turn for her protein supplies more and more to the resources of the sea. On her west coast the cold, productive Benguela Current maintains extensive fisheries for pilchard, hake and snoek, and to the south is the flatfish ground of the Agulhas Bank. The demands of research and development in these areas may be expected, in the future as in past years, to preoccupy the attention of the Division of Fisheries, Cape Town, whose research ships have already done valuable work on the west and south coasts. On the other hand, the resources of the east coast remain practically unknown : the seas between Mozambique and East London, except for certain excellent studies of the littoral fauna, have scarcely been explored by fishery biologists or oceanographers. It is therefore most encouraging to learn that this neglect is shortly to ke remedied by the building of a new and extensive marine research station at Durban in the province of Natal. Funds for the project are being subscribed by the recently founded South African Association for Marine Biological Research*.

" "South African Association for Marine Biological Research" (Central Press, Durban, 1953).
What purely faunistic surprises may await the investigator are suggested by the discovery of the first cœlacanth off East London in 1938 and, in the past year or two, of other specimens in the Mozambique Channel. Apart from the colacanth, however, the diversity and fascination of the problems awaiting solution in this region, contrasted with the seant attention it has received, greatly impressed me during the voyage of the Royal Research Ship William Scoresby in 1950 when, in the midst of a whale-marking cruise, the ship conducted a limited amount of oceanographical work and experimental fishing across the Mozambique Channel and in the Agulhas Current opposite East London. Because the area is extensive, the work of other expeditions, though valuable, has been no less incomplete. The R.R.S. Discovery II has worked some oceanographical stations up the Mozambique Channel and in the Agulhas Current off Durban, including a few extending eastward into the West Indian Ocean. On the coast banks some experimental trawling has been done by the Africana from the south towards Durban. The abyssal fauna of the oceanic region remained unexplored until 1951 when the Galathea, by several successful hauls in latitudes around Durban and in the Madagascar Deep, indicated the scope for work of this kind. These fragmentary investigations are no more than pointers for an oceanographical survey, complete in its widest sense, which the waters east of Africa deserve and which offer a fund of problems to the South African Association for Marine Biological Research.

A great deal has yet to be learned about the hydrology of the south-east African region. To the south of Madagascar the Mozambique Current is augmented by another arm of the Trade Wind Drift and flows southward, following the line of the African coast, as the warm, swift Agulhas Current. Between the main current and the cocst there is a minor stream of cold water, of variable extent and velocity, which sets to the northward. So far as I am aware, nobody has yet investigated the origins of this counter-current, or its effects on the organic productivity of the coastal area. Hydrological survey of the counter-current may also suggest means of controlling the banks of shifting sand which are caused by this current and which at present are a major problem to the engineers of Durban harbour. One of the most interesting yet least understood. things about the main Agulhas Current is the likely presence of marginal upwelling. This phenomenon is something quite distinct from the counter-current and is believed to occur when the main current is accelerated, as by strong winds, so that the denser. water (which in the southern hemisphere always flows on the right-hand side of a current system) is brought to the surface on the inshore side of the current by hydrodynamic forces. Such marginal upwelling of nutrient-rich cold water, adjacent to or over a coast bank, may be sufficient to increase the productivity of waters available for fishing.

The most obvious biological effect of the Agulhas Current is the environmental one regarding the physical and chemical parameters it establishes for the fauna, including the economically important fish fauna. Temperature is most important. The current in the Mozambique Channel has a warm-water fauna of Indo-Pacific character. As the current moves southward it becomes cooler, approaching the region of the West Wind Drift off the extreme south coast of Africa. So it happens that the sea off the coast 
of Natal is a region of transition where Indo-Pacific forms mingle with elements of the temperate Cape fauna. All authorities are agreed that the Natal area is very rich in species, and as a transitional region it is specially attractive to the taxonomist and ecologist and to the scientist interested in problems of evolution. Prof. J. L. B. Smith has studied intensively, though he would not wish to say exhaustively, the littoral fishes of Natal, and Prof. T. A. Stephenson and his colleagues have examined the ecology of the littoral invertebrates; but less attention has so far been paid to transitional problems in the neritic and oceanic faunas which include the actual or potential species of major economic importance. Thus the Cape hake sometimes extends to the Natal region and, especially in winter, may even appear in great. shoals. Practically nothing is at present known of this seasonal invasion. The Cape snoek (Thyrsites) does not penetrate into Natal waters, where the local 'snoek' is a species of Scomberomorus; but the possibility of exploiting Scomberomorus on a large scale might be investigated.

Among the oceanic fishes of the current, the giant scomberoids, like the tunny, may be sufficiently abundant to allow a regular fishery. The tunny at the present time is everywhere becoming increasingly popular as a food fish. A survey of the myriad shoals of flying fish would not only be important in regard to the distribution and possible migrations of the tunny and albacore which prey on them, but also would be important in itself, for flying fish are excellent eating and in California and Barbados they are fished on a commercial scale.

Any wide survey may discover new fishing banks. The search far afield need not be disregarded. Off the south coast of Madagascar lies the Star Bank, where I have myself hauled the trawl and been impressed by the wealth of fauna : the Star Bank certainly deserves a fishing survey. On the coast banks of Natal itself there is an abundance of sharks. The shark fishery which once existed at Durban might be revived if attention could be given to such problems as extracting the liver oil, refrigerating, salting and packaging the meat, preparing meat meal, shark leather and shagreen, and marketing these products.

Technical problems of this kind would doubtless be included in the scope of the new station. Its aquarium also (which will be a major feature of the building) could be used not only for purely biological studies but also for such technical investigations as the development of electric fishing methods.

There may be several potential inshore fisheries awaiting the results of survey and research. In South Africa eels are only found in rivers flowing east to the Indian Ocean, and the story of their spawning migration has still to be told. Pearl oysters occur in the Natal area and there are possibilities for oyster-farming on a commercial scale. Some extremely interesting surveys by. Prof. J. H. Day and his colleagues have indicated the abundance of prawns and fish in certain estuaries on the Natal coast. There may be opportunities here for farming of a kind which has been very successful in many parts of Asia. Furthermore, the abundant penæid prawns (which in Natal take the place of the Cape crawfish) are thought to be migratory, and the tracing of these migrations may lead to an offshore prawn fishery like that discovered in deep water by the late Prof. Johan Hjort and made into a considerable industry in Norwegian seas.
Although territorial problems may need to be settled, an oceanographical survey which includes the Madagascar seas might find the search for guano worth while: it is possible that on such islands as Europa Island there are exploitable deposits of seabird guano.

Whaling is conducted from the Bluff at Durban, so the new marine station may expect to have excellent opportunities for research on whales and the special problems of the whaling industry. Here is a field for investigations of great economic importance, for Durban takes mostly humpback and sperm whales, the life-histories of which are still imperfectly known. Apart from two seasons work by the former Discovery Committee's staff in 1926 and 1930, and some whale marking by the William Scoresby in 1950 , there seems to have been no research on these stocks in their migrations along the waters east of Africa.

By establishing the new marine station in a subtropical area, the South African Marine Biological Association reflects that interest in the possible resources of warm seas which since the Second World War has led to the setting up of research centres on several tropical seaboards of the British Commonwealth and the Colonies. These are government institutions, but it seems that most of the funds for the Durban Station are being raised from the subscriptions of private citizens. We wish the Association well.

\section{PURIFIED CASEIN FOR NUTRITIONAL RESEARCH}

\section{By ALICE M. COPPING}

Queen Elizabeth College, University of London

$\mathrm{N}$

UTRITIONAL experiments for the past thirty years have progressively emphasized the noed for a source of protein which is pure and of high biological value, and it has come to be realized that casein is the most suitable protein for experiments with such small animals as rats, mice and chicks and such large animals as pigs. Latterly, it has been used also in experiments with insects and in microbiological studies. Casein is the principal but not the only protein providing the food of the growing calf, and its high biological value has been demonstrated by Karl Thomas ${ }^{1}$, by $\mathrm{McCollum}^{2}$, by Chick and coworkers ${ }^{3}$ and by many others using various techniques. It contains all the essential amino-acids though the relative amount of the sulphur aminoacids is rather low, so that experimental diets are more certain to be satisfactory when they contain about 20 per cent of casein than if they have less than 10 per cent. The low content of sulphur aminoacids has to be remembered in choosing the methods for purifying casein, care being needed to avoid damage to them.

By 1929, when Coward ${ }^{4}$ reported the occurrence of a growth factor, different from the then recognized vitamins, in light white casein it was known that purification by washing and extraction was essential to give a casein that could be used satisfactorily in diets for studying vitamin $A$ and the $B$ vitamins. At this point it is relevant to give some description of the types of casein products available for biological studies. Light white casein, to which reference is made above, is not a true casein but a caseinate 